\title{
Commercially available antibiotic-laden PMMA-covered locking nails for the treatment of fracture-related infections - A retrospective case analysis of 10 cases
}

\author{
Alberto Jorge-Mora 1,2,3凶; Samer Amhaz-Escanlar1,2; Sabela Fernandez-Pose ${ }^{1}$; Adrián García-Iglesias ${ }^{1}$, \\ Fermín Mandia-Mancebo, ${ }^{1,2}$; Eloi Franco-Trepat ${ }^{3}$; María Guillán-Fresco3 ${ }^{3}$ Jesús Pino-Minguez ${ }^{1,2}$ \\ 1. Division of Traumatology, Santiago University Clinical Hospital, Santiago de Compostela, Spain \\ 2. Faculty of Medicine, University of Santiago de Compostela, Spain \\ 3. Musculoskeletal Pathology Group, Laboratory 18, Institute IDIS, Servicio Galego de Saúde, Santiago de Compostela, Spain \\ $\bowtie$ Corresponding author: Alberto Jorge-Mora aljmora@gmail.com \\ (C) The authors. This is an open access article distributed under the terms of the Creative Commons Attribution (CC BY) license (https://creativecommons.org/licenses/ \\ by/4.0/). See http://ivyspring.com/terms for full terms and conditions.
}

Received: 2019.02.13; Accepted: 2019.05.21; Published: 2019.07.05

\begin{abstract}
Introduction: Fracture-related infections (FRIs) are a devastating complication. FRIs are challenging and should be addressed with a multidisciplinary approach. An FRI should be addressed surgically by non-viable bone debridement, local antibiotic deposition, minimization of dead space and fracture stabilization. Antibiotic-laden PMMA-covered nails are a viable option to face these complications. To demonstrate the safety and utility of commercially available antibiotic-laden PMMA-covered nails, we performed a review of the cases operated in our institution and a cost analysis to compare the cost of a commercial nail to other available alternatives.

Material and methods: We designed a retrospective study of consecutive cases to demonstrate the safety and efficacy of antibiotic-laden PMMA-covered commercial nails and designed a cost analysis of commercial coated nails compared to other custom-made alternatives.

Results: We treated seven tibias and three femurs. Nine patients fully fit the criteria for FRI. There was one case of reintervention because of persistent drainage. All fractures healed, and in the first year post-intervention, there were no signs or symptoms of infection. There were no complications related to the commercially available nail that was used. There is a small increase in the direct quantifiable cost in commercially available nails, but non-quantifiable cost should be assessed individually.

Conclusions: Commercially available antibiotic-laden PMMA-covered nails are a safe and useful treatment option for complicated cases of lower limb long bone reconstruction. The low complication rate and the straightforward technique compensate for the direct cost increase in most situations.
\end{abstract}

Key words: Infection; long bone; antibiotic-laden PMMA-covered nail; fracture-related infection

\section{Introduction}

Long bone fractures are common [1], and it seems that there is an increase in the incidence of these fractures in elderly people [2]. The infection rates of orthopaedic trauma procedures depend on the patient, the procedure and the injury sustained, and the infection rate differs among publications

\section{$(2.9-14.2 \%)[3-5]$}

One of the major troubles regarding evidence in this field is the lack of consensus in older reports about the definition of fracture-related infection (FRI), which makes these publications difficult to integrate. The definition of FRI has not been validated in most of 
these studies [6]. Recently, a consensus has arrived, with confirmatory and suggestive criteria to provide more homogeneity among publications [7]. Similar to periprosthetic joint infection, these new criteria are based on clinical exams, medical history and surgical findings.

FRIs are challenging and should be addressed by a multidisciplinary approach: orthopaedic surgeons, plastic surgeons, infectious disease specialists, etc. All specialists should be involved in the management of these difficult-to-treat complications [8, 9]. From an orthopaedic perspective, the presence of an FRI in a long bone should be managed surgically in different ways, but all strategies should include non-viable bone debridement, local antibiotic deposition, minimization of dead space and fracture stabilization [10]. All of these strategies work to control and eradicate infection.

To achieve these goals, we can find new procedures and materials in the field of FRIs to facilitate treatment. The use of the reamer/irrigation/aspiration (RIA) system for intramedullary reaming (DePuy Synthes) has simplified the debridement procedure in long bones and has become an essential tool in our daily practice [11]. The use of antibiotic-laden PMMA-covered nails has helped in the management of dead space, local antibiotic delivery and fracture stabilization [12-14].

The use of antibiotic-laden PMMA-covered nails has increased in the orthopaedic community since their popularization by Paley in 2002[15], and now we can find them employed in numerous publications $[12,16-22]$. In most of these publications, as recently described by Wasko et al. [23], the nails used are custom-made with different techniques and procedures. We can find surface modification treatments (Gentamicin poly(D, L-lactide) matrix coating for tibia nails, silver coating or iodine coating) designed to minimize colonization in implants used in high-risk patients, but there are no treatments specifically for FRI [24, 25]. Recently, some authors have advocated the use of PMMA custom-made plates for periarticular infected fractures [26], but their use is still limited.

Custom-made nails have the theoretical advantage of lower costs and the opportunity to select different antibiotics for local delivery, but not all antibiotics are able to be carried in PMMA. Antibiotics for this purpose should have specific physico-chemical properties [27]: high solubility in water, thermostability to prevent degradation during polymerization, beneficial or non-deleterious to the mechanical properties of the PMMA, and should elute adequately from the polymeric matrix of the cement. There are also some desirable biological properties associated with the antibiotic selected[27]: high spectrum of action (gram-positives and gram-negatives), low-dose bactericidal action, low antibiotic resistance, low protein-binding rate, minor allergic characteristics and proper bone and cell penetration. All of these properties make gentamicin a good choice for obtaining an optimal concentration of antibiotic locally while causing minimal systemic complications [28].

These custom-made nails have some disadvantages: first, their use is off-label, and custom-made implants should be explained to the patient with consent received prior to surgery. The surgeon should be familiar with the procedure to prevent errors that lead to complications (for example, selecting rifampicin or metronidazole, or mixing liquids with powder [29]). It is important to note that all materials used at this point should be validated for medical use, and silicone moulds must be thermal resistant to minimize degradation during polymerization (plastics, polyvinylchloride). Second, the use of non-industrial devices, manually generated, is not reproducible in most cases, and the PMMA mantle and antibiotic elution can be different between implants constructed in the same manner [30]. Third, some authors have created antibiotic-laden PMMA-covered locking custom-made nails [22], but not all described techniques provide a locking nail to achieve stability; some only act as spacers [31, 32]. Finally, the mantle of PMMA could be removed easily during insertion of the custom-made implant, complicating future hardware extraction and generating free PMMA pieces/particles in the medullary canal (Figure 1 A) [31]. Added to these inconveniences, we must include the waste of time dedicated to the fabrication of the nail, which increases surgical time and costs.

Recently, some manufactures have developed antibiotic-laden PMMA-covered locking nails as an alternative to custom-made nails. These implants have the great advantage of minimal time consumption. These nails are solid, not-cannulated, to prevent bacterial colonization and dispersion through the canal (this point should be considered because the absence of a rod to guide the nail may make its insertion difficult). The antibiotic-laden PMMA cover is uniform without weak zones (Figure $1 \mathrm{~B}$ ). The nail is locked to increase stability. Finally, the elution of antibiotics from these nails is regular and is similar among implants. The two major disadvantages are limited antibiotic availability in the PMMA and the increased costs of the material.

To demonstrate the safety and utility of commercially available antibiotic-laden PMMAcovered nails, we have performed a review of the 
cases in our institution. We also performed a cost analysis to compare the cost of a commercial nail to a custom-made nail.

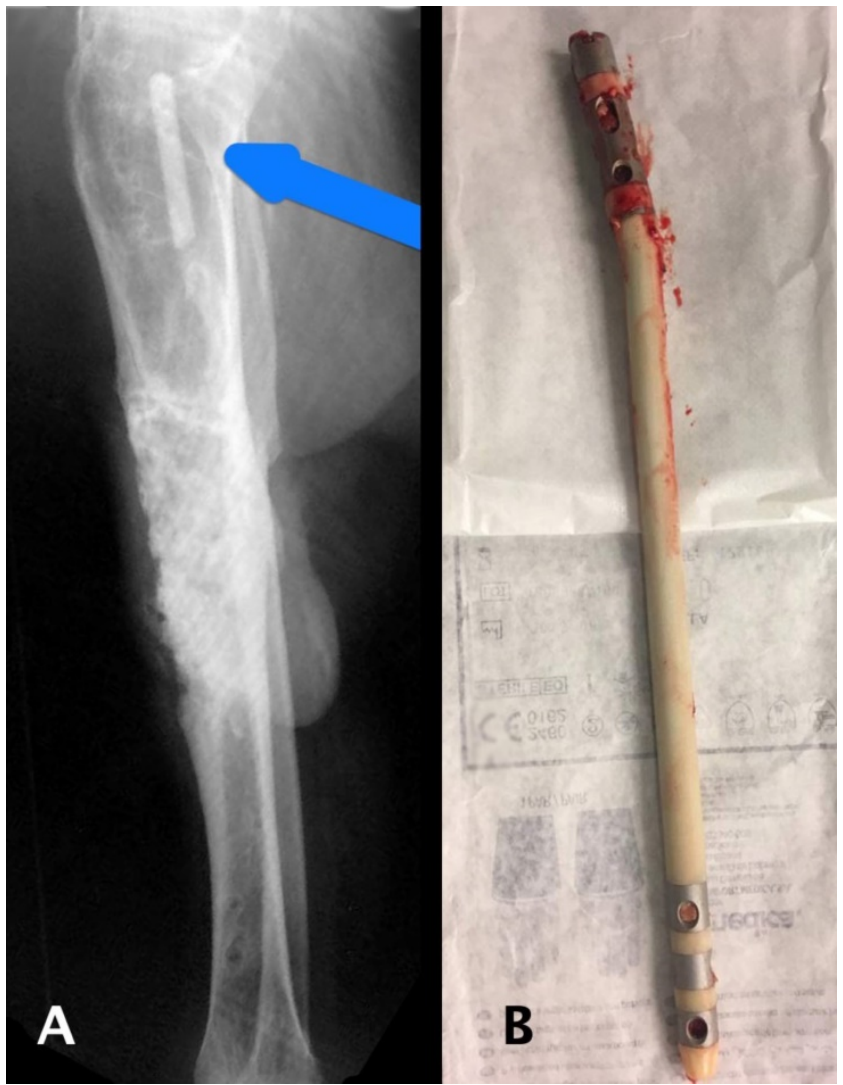

Figure 1: A: A lateral $X$-ray shows a broken piece of PMMA in the diaphysis of a tibia after a reconstructive process, indicated by the arrow. B: Image of a nail without mantle break after removal.

\section{Material and Methods}

We designed a retrospective study of consecutive cases to demonstrate the safety and efficacy of an antibiotic-laden PMMA-covered commercial nail with a controlled elution of antibiotics. We also designed a cost analysis of commercial coated nails compared to a custom-made alternative in our institution.

This review was approved by our Ethics Committee.

\section{Patients}

We completed a retrospective review of all patients who underwent an operation in our institution that included a commercially available antibiotic-laden PMMA-covered nail (Synicem clous, Synimed) with a minimum follow-up of 12 months.

We included 10 patients with a fracture sequela, including a subacute or chronic septic complication of a long bone in the lower limb. We included 9 males and 1 female. There were no patients excluded.

\section{Intervention}

In all situations, we performed the same approach. Initially, all injuries were studied by clinical examination and complementary tests. Standard X-rays, blood tests and computed tomography with intravenous contrast images were routinely obtained. If necessary, we completed the medical records with MRI images.

During the operation, we initially executed an aggressive resection of the dead and non-viable bone, and later we performed a complete reduction of the injury if needed, including temporal stabilization with the aid of an $\mathrm{AO}$ distractor. In the next step, we systematically use the RIA for intramedullary debridement [33]. Afterwards, we implant the antibiotic-laden PMMA-covered nail (Synicem clous, Synimed) with locking screws. We select a nail $1 \mathrm{~mm}$ thinner than the diameter of the reamer selected for reaming. Depending on the case, injuries were managed in one or two stages (Figure 2). In cases in which we have to add PMMA for a bone defect, we load the cement with specific antibiotics according to the antibiogram and the pathogen characteristics.

A minimum of five tissue samples (bone and soft tissue) are obtained for culture.

If we decided to complete a two-stage procedure for bone defects (induced membrane technique [34]) and we need to fill a bone gap with PMMA, there is a high risk of polymerization of the PMMA at the surface of the nail. To prevent this, we cover the exposed surface of the nail with a small quantity of bone wax. This will avoid a mantle break during PMMA removal in the second stage, and it will be easy to separate the nail from the PMMA.

In cases where soft tissue coverage is planned, plastic surgeons complete this step during the same surgery.

After the injury is healed, we remove the antibiotic-laden PMMA-covered nails according to the manufacturer's recommendations, unless the patient rejects hardware removal.

Antibiotic treatment is determined by operative cultures. Until we receive positive culture results, we systematically use vancomycin and meropenem for empirical treatment [35].

\section{Variables and outcomes}

We include demographic characteristics for every patient. In all cases, we documented the bone affected, the bacteria responsible for the infection obtained by surgery cultures (minimum of two different samples) and the injury mechanism.

We diagnosed an FRI in those patients who fulfilled the criteria recently described by Metsemakers et al [7]. 
As a positive early outcome, we accepted a patient with a normalization of acute phase parameters (erythrocyte sedimentation rate, C-reactive protein and leukocyte levels), with no local pain, no clinical signs of infection and a consolidated fracture without the need for unplanned interventions (defined as an intervention not planned in the reconstructive process).

We also recorded complications related to the surgical process and complications related to the hardware (antibiotic-laden PMMA-covered nail).

\section{Cost analysis}

We studied the cost difference between commercially available nails and custom-made nails. We studied the direct quantifiable costs in our environment. We included the cost of the nail, the PMMA used and the instruments needed to construct the PMMA nail, and the surgical time dedicated to the generation of the custom-made nail (estimated to be approximately 15 euros per minute by Antares Consulting y General Electric Healthcare in Spain).

\section{Results}

\section{Patients}

We included 10 consecutive patients with a median age of 45.3 years (range 22-63). We included 7 patients with a tibial injury and 3 patients with a femoral injury. Table 1 describes the cases and the bacteria responsible for the infection.

In our series, there were 6 patients with a septic non-union or a subacute infection after fracture fixation/stabilization and 3 patients with a posttraumatic chronic osteomyelitis with an acute exacerbation of the infection with a diaphyseal sequestrum that needed fracture stabilization after debridement.

All patients were type A and B of Cierny and Maden, and most injuries were stage IV (Table 1).

There was only one patient with negative cultures (Figure 2). This patient suffered a tibial non-union with a varus collapse. The patient was treated overseas multiple times. The infection was treated previously by an induced membrane technique [34] with no signs of consolidation and a varus deformity. In this case, because the preoperative test and operative strain were favourable, we chose a one-step procedure to treat the non-union.

Nine patients fulfilled the criteria for FRI, with a minimum of two operative cultures positive for the same pathogen.

\section{Complications} database.
One patient, because of medical treatment, suffered agranulocytosis. This condition was resolved by treatment adjustment and granulocyte colony stimulating factor.

There was one case of persistent drainage (after 3 days) that was treated by surgical lavage and direct closure with full resolution.

There were no complications related to the material, no PMMA mantle break, no complications during hardware removal, and in those cases where we used PMMA over the nail (as described in the surgical technique procedure), we had no polymerization between the PMMA and the surface. There were no unexpected events during PMMA removal (Figure 1B).

Two patients refused hardware removal with annual control in our outpatient clinic without complications at the last follow-up.
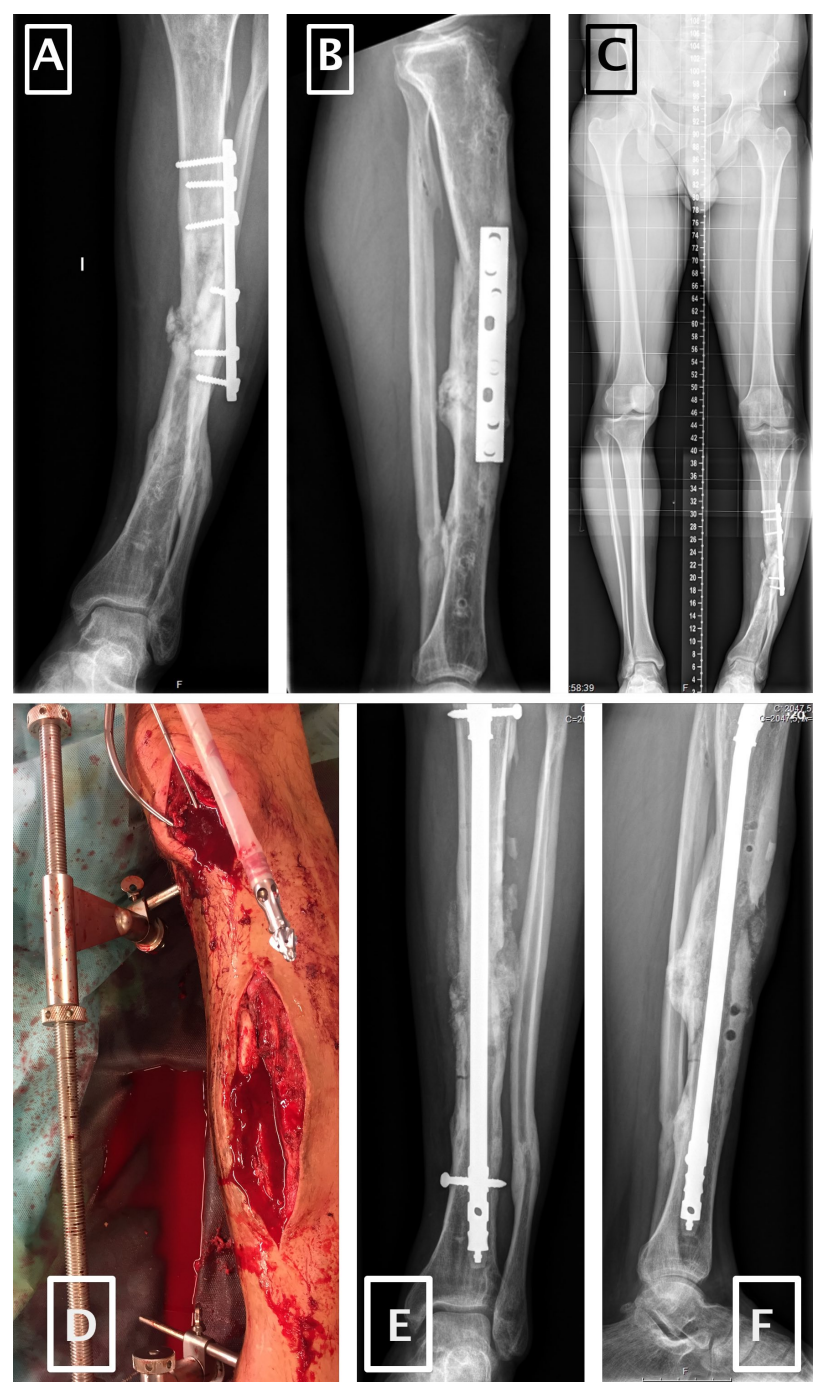

Figure 2: Images that show the reconstructive steps of a tibial non-union. Images $\mathbf{A}$ and $\mathbf{B}$ : Anteroposterior and lateral X-ray. Image $\mathbf{C}$ : Teleradiograph in full-weight. Image D: Intraoperative correction with a distractor and RIA reamer. Images E and F: postoperative anteroposterior and lateral $\mathrm{X}$-ray after non-union treatment. 
Table 1: Demographic characteristics, bacteria responsible for infection and a description of the case.

\begin{tabular}{|c|c|c|c|c|c|c|c|c|c|}
\hline № & Bacteria & Age & Gender & $\begin{array}{l}\text { Cierny and } \\
\text { Maden }\end{array}$ & Bone & Description of the case. & $\begin{array}{l}\text { Criteria } \\
\text { for FRI }\end{array}$ & Complication & $\begin{array}{l}\text { Mechanism of } \\
\text { initial injury }\end{array}$ \\
\hline 1 & $\begin{array}{l}\text { Enterococcus } \\
\text { faecalis }\end{array}$ & 22 & Male & $\mathrm{A} / \mathrm{I}$ & Tibia & $\begin{array}{l}\text { Infection } 5 \text { months after tibial } \\
\text { nailing. Fistula in fracture } \\
\text { focus. }\end{array}$ & Yes & None & $\begin{array}{l}\text { Low energy, close } \\
\text { fracture }\end{array}$ \\
\hline 2 & $\begin{array}{l}\text { Staphylococcus } \\
\text { aureus }\end{array}$ & 50 & Male & $A / I I I$ & Tibia & $\begin{array}{l}\text { Closed fracture treated with a } \\
\text { nail, complicated by an acute } \\
\text { infection, not responding to } \\
\text { debridement and antibiotics. }\end{array}$ & Yes & None & $\begin{array}{l}\text { Low energy, close } \\
\text { fracture }\end{array}$ \\
\hline 3 & Salmonella typhi & 50 & Male & $\mathrm{A} / \mathrm{IV}$ & Femur & $\begin{array}{c}\text { Chronic osteomyelitis. } \\
\text { Sequestrum. }\end{array}$ & Yes & None & $\begin{array}{l}\text { Low energy, } \\
\text { closed fracture }\end{array}$ \\
\hline 4 & $\begin{array}{l}\text { Klebsiella } \\
\text { pneumoniae }\end{array}$ & 43 & Male & $\mathrm{B} / \mathrm{II}$ & Tibia & $\begin{array}{l}\text { Closed refracture treated with } \\
\text { a nail, complicated by a } \\
\text { subacute infection, not } \\
\text { responding to debridement } \\
\text { and antibiotics. }\end{array}$ & Yes & None & $\begin{array}{l}\text { Low energy, } \\
\text { closed fracture }\end{array}$ \\
\hline 5 & $\begin{array}{l}\text { Enterobacter } \\
\text { cloacae }\end{array}$ & 43 & Male & $\mathrm{B} / \mathrm{IV}$ & Tibia & $\begin{array}{c}\text { Septic non-union with } 5 \text { prior } \\
\text { surgeries. }\end{array}$ & Yes & None & $\begin{array}{l}\text { High energy, } \\
\text { closed fracture }\end{array}$ \\
\hline 6 & $\begin{array}{l}\text { Staphylococcus } \\
\text { aureus }\end{array}$ & 55 & Female & $\mathrm{B} / \mathrm{IV}$ & Femur & $\begin{array}{c}\text { Fracture in an osteomyelitic } \\
\text { bed. }\end{array}$ & Yes & None & $\begin{array}{l}\text { Low energy, close } \\
\text { fracture }\end{array}$ \\
\hline 7 & Pseudomona spp & 28 & Male & A / IV & Tibia & $\begin{array}{l}\text { Infected IIIC fracture with } \\
\text { bone defect. Secondary } \\
\text { reconstruction. }\end{array}$ & Yes & Agranulocitosys & $\begin{array}{l}\text { High energy, open } \\
\text { fracture }\end{array}$ \\
\hline 8 & $\begin{array}{l}\text { No bacteria in } \\
\text { cultures }\end{array}$ & 40 & Male & & Tibia & $\begin{array}{c}\text { Postraumatic nonunion, with a } \\
\text { varus deformity }\end{array}$ & No & None & $\begin{array}{l}\text { High energy, } \\
\text { closed fracture }\end{array}$ \\
\hline 9 & $\begin{array}{l}\text { Staphylococus } \\
\text { epidermidis }\end{array}$ & 63 & Male & $\mathrm{B} / \mathrm{IV}$ & Tibia & $\begin{array}{l}\text { Active chronic osteomyelitis. } \\
\text { Sequestrum. }\end{array}$ & Yes & $\begin{array}{l}\text { Persistent } \\
\text { drainage }\end{array}$ & $\begin{array}{l}\text { Low energy, close } \\
\text { fracture }\end{array}$ \\
\hline 10 & $\begin{array}{l}\text { Staphilococus } \\
\text { haemolyticus }\end{array}$ & 59 & Male & $\mathrm{B} / \mathrm{IV}$ & Femur & $\begin{array}{l}\text { Active chronic osteomyelitis. } \\
\text { Sequestrum. }\end{array}$ & Yes & None & $\begin{array}{l}\text { Low energy, open } \\
\text { fracture }\end{array}$ \\
\hline
\end{tabular}

\section{Main outcomes}

One year after the main procedure, all patients were alive.

Antibiotics were discontinued in all patients after a maximum of 3 months, with normalization of acute phase markers, no pain or new symptoms of infections, and no complementary tests suggesting complications.

All injuries healed without unplanned surgical procedures, except for one patient who needed an unexpected intervention because of persistent drainage, as previously described.

In those cases where nails were removed, cultures obtained during hardware removal were negative in all samples.

\section{Cost analysis}

The direct cost of a custom-made nail, in those situations where there are no complications when performing the procedure, is 1747 euros (Table 2). The cost of a unitary commercially available antibiotic-laden PMMA-covered nail is 2820 euros. There is an increase in the cost by 1073 euros. This difference between the cost of both treatment options is the maximum obtained difference, excluding non-quantifiable costs, and can be minimized depending on the number of nails used. We also must deduct the wages of the orthopaedic team.
Table 2: The cost of an antibiotic-laden PMMA-covered custom-made nail compared to a commercially available nail.

\begin{tabular}{|c|c|c|}
\hline COSTS & $\begin{array}{c}\text { Commercially available } \\
\text { antibiotic-laden } \\
\text { PMMA-covered } \\
\text { locking nail }\end{array}$ & Manufactured nail \\
\hline Nail & 1047 & 2820 \\
\hline $\begin{array}{c}\text { Pmma }+ \\
\text { antibiotic }\end{array}$ & 100 & 0 \\
\hline PMMA mixer & 150 & 0 \\
\hline Silicone tube & 20 & 0 \\
\hline Theatre time & $15 \times$ min & 0 \\
\hline TOTAL & 1747 & 2820 \\
\hline
\end{tabular}
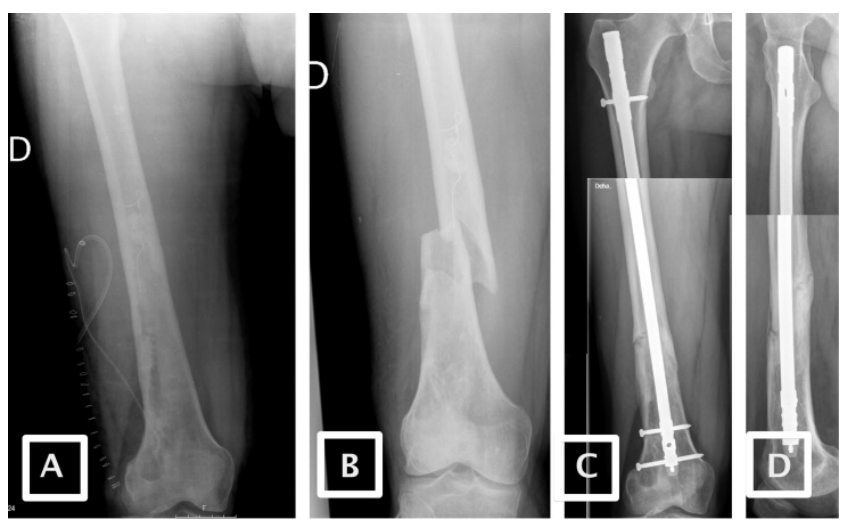

Figure 3: Image A: Postoperative image of the debridement of a sequestrum. Image B: Acute postoperative fracture after debridement. Images $\mathbf{C}$ and $\mathbf{D}$ : Anteroposterior and lateral X-ray after fixation. 
Non-quantifiable costs may minimize or change the previous cost difference. We have to include the costs derived from errors during the cementation of the nail, problems with the PMMA mantle, the surgical time dedicated to generating the nail (estimated as a minimum of 30 minutes), and an increase in complications associated with a longer operative time.

\section{Discussion}

As previously discussed, FRIs are challenging for orthopaedic surgeons and also for a national health systems because of their burden, which doubles the standard cost of a primary fracture treatment and impairs the recovery of the patient[36].

The recent development of a consensus in FRI [7, 37] has favoured consistency in the diagnosis of infection after fracture fixation, which is the first step toward improving homogeneity in publications and optimizing fracture management.

We have performed a retrospective study of our initial outcomes obtained with commercially available antibiotic-laden PMMA-covered nails to demonstrate their utility and safety. In our review, there were no hardware-related complications, even in those cases where patients refused removal. Surgical site infection in patients diagnosed with FRI was controlled in all situations. In those fractures where the antibiotic-laden PMMA-covered nail was used as a definitive fixation device, the fractures healed uneventfully. In those situations where the nail was used as a spacer, there were no hardware failures, and infection was controlled prior to the reconstructive surgery, as demonstrated by the negative intraoperative cultures and normalization of acute parameters.

There is no consensus about FRI cure, and there are no definitive parameters validated for this situation. Clinically, we can only discuss controlled infection, and most series use clinical evaluation, acute phase markers and complementary tests to evaluate a controlled infection [31]. In our series, we chose these data to define a controlled infection. We also obtained fracture consolidation and good soft tissue coverage to improve function [38].

We cannot confirm that all of the improvement was secondary to the nail because management of FRI includes multiple steps that optimize the outcome. RIA reamer has proven to be an effective strategy for intramedullary infection control [33]. The use of appropriate local and systemic antibiotics decreases bacterial ingrowth [39]. A nail with controlled antibiotic elution (maintained for more than 3 weeks) allowed reproducibility between patients and straightforward treatment. The creation of multidisciplinary teams maximizes treatment outcomes [9, 40,41]. The use of antibiotic-coated nails is one more step, and commercially available nails seem to be safe and effective.

Pradhan et al.[20], in a series of 21 patients treated because of an infection with an intramedullary antibiotic-laden PMMA-covered nail, reported 2 cases of hardware failure because of nail breakage, one case of non-union and several cases of lower limb discrepancy in patients treated with a custom-made nail without locking screws. We can see the importance of locking screws in periprosthetic fractures around the knee treated with a nail, and we can improve consolidation rates by increasing the number of locking screws [42], which may also be beneficial in infections. There are no reports of PMMA mantle complications in these series. In a recent review, there were multiple complications related to the hardware when managing infections with custom-made nails, and a series with a report of $20 \%$ PMMA mantle break. [31]. To prevent these complications, an over-reaming of a minimum of 2 $\mathrm{mm}$ has been proposed [43], but this requires the use of small nails or aggressive reaming to use a wider nail. We did not have hardware complications in our 10-patient cohort. With the use of commercial nails, 1 $\mathrm{mm}$ of over-reaming is enough to prevent complications, maximizing the bone-implant contact and minimizing the dead space around the nail. Before the use of commercial nails, mantle break off was common in our practice, as can be seen in Figure $1 \mathrm{~A}$.

As we have shown, direct costs in antibiotic-laden PMMA-covered commercially available nails are higher than custom-made nails. The burden of an infection doubles the costs of a fracture treated without complications, with an average increased cost of 100,000 dollars in United States currency [36] and approximately 81,000 euros in European currency if we search for tibial infected fractures that need soft tissue coverage [44]. In the case that we selected, a commercially available nail, we should only assume a maximum increase of $1 \%$ in costs in these situations.

At this time, we can only choose between two antibiotics in commercially available nails in our environment (gentamycin and tobramycin), but there are vancomycin nails available abroad. This point should be addressed by industry to provide more options to treat resistant bacteria because this is a handicap in our daily practice. In our series, we only chose gentamicin-coated nails. For cases infected by bacteria with specific resistance, for example, enterococcus with Gentamicin and Streptomycin High-Level Aminoglycoside Resistance (HLAR), we 
still use custom-made nails with adequate antibiotics. Despite this handicap, gentamycin-loaded PMMA is not inferior for infection control compared to vancomycin plus gentamycin-loaded PMMA [45].

There is recent evidence that supports the use of gentamicin covered nails to treat primary open tibial fractures [16, 25]. Most of these studies use different surface treatments than our series (a fully resorbable antibiotic coating consisting of an amorphous poly(D,L-lactide)), and indications for these nails include prevention of infection in acute fractures or shaft fractures, but there is no indication for FRI. The use of antibiotic-laden PMMA-covered nails may also be an option for acute fractures with a high risk of infection. The use of these nails for all open fractures should be validated. In our study, we used an antibiotic-laden PMMA-covered nail for a patient who sustained an acute fracture in an osteomyelitic bone after debridement, and the outcome was favourable, as can be seen in image 3 .

In our series, there were no cases of delayed healing when an antibiotic-laden PMMA-covered nail was used as definitive treatment, but the role of PMMA in fracture healing should be studied because PMMA can inhibit osteoblast activity [46].

There are multiple limitations in our study. First, it is a retrospective study of consecutive cases. The patients are heterogeneous but were treated with the same procedure. Our follow-up is short, and it was common that some of our patients continued with an infection that was activated in the future. There is no consensus about an FRI cure, and we have selected the most frequent parameters used in similar publications. Cost analyses are related to our country of practice and can vary substantially between countries and hospitals. Long-term studies with retained antibiotic-laden PMMA-covered nails should be made to confirm this short-term low complication rate in cases of refusal to remove hardware.

\section{Conclusions}

Commercially available antibiotic-laden PMMA-covered nails are a safe and useful treatment option for complicated cases. The low complication rate and the straightforward technique compensate for the direct cost increase in most situations.

\section{Competing Interests}

The authors have declared that no competing interest exists.

\section{References}

1. Court-Brownd CM, Clement ND, Duckworth AD, Biant LC, McQueen MM. The changing epidemiology of fall-related fractures in adults. Injury. 2017; 48: 819-24.
2. Court-Brown CM, McQueen MM. Global Forum: Fractures in the Elderly. J Bone Joint Surg Am. 2016; 98: e36.

3. Doshi P, Gopalan H, Sprague S, Pradhan C, Kulkarni S, Bhandari M. Incidence of infection following internal fixation of open and closed tibia fractures in India (INFINITI): a multi-centre observational cohort study. BMC Musculoskelet Disord. 2017; 18: 156.

4. Harwood PJ, Giannoudis PV, Probst C, Krettek C, Pape HC. The risk of local infective complications after damage control procedures for femoral shaft fracture. J Orthop Trauma. 2006; 20: 181-9.

5. Backes M, Dingemans SA, Dijkgraaf MGW, van den Berg HR, van Dijkman B, Hoogendoorn JM, et al. Effect of Antibiotic Prophylaxis on Surgical Site Infections Following Removal of Orthopedic Implants Used for Treatment of Foot, Ankle, and Lower Leg Fractures: A Randomized Clinical Trial. JAMA. 2017; 318: 2438-45.

6. Metsemakers WJ, Kortram K, Morgenstern M, Moriarty TF, Meex I, Kuehl R, et al. Definition of infection after fracture fixation: A systematic review of randomized controlled trials to evaluate current practice. Injury. 2018; 49: 497-504

7. Metsemakers WJ, Morgenstern M, McNally MA, Moriarty TF, McFadyen I, Scarborough $\mathrm{M}$, et al. Fracture-related infection: A consensus on definition from an international expert group. Injury. 2018; 49: 505-10.

8. Ali AM, McMaster JM, Noyes D, Brent AJ, Cogswell LK. Experience of managing open fractures of the lower limb at a major trauma centre. Ann R Coll Surg Engl. 2015; 97: 287-90.

9. Bose D, Kugan R, Stubbs D, McNally M. Management of infected nonunion of the long bones by a multidisciplinary team. Bone Joint J. 2015; 97-B: 814-7.

10. Bonnevialle P. Operative treatment of early infection after internal fixation of limb fractures (exclusive of severe open fractures). Orthop Traumatol Surg Res. 2017; 103: S67-S73

11. Tosounidis TH, Calori GM, Giannoudis PV. The use of Reamer-irrigator-aspirator in the management of long bone osteomyelitis: an update. Eur J Trauma Emerg Surg. 2016; 42: 417-23.

12. Wasko MK, Borens O. Antibiotic cement nail for the treatment of posttraumatic intramedullary infections of the tibia: midterm results in 10 cases. Injury. 2013; 44: 1057-60

13. Conway J, Mansour J, Kotze K, Specht S, Shabtai L. Antibiotic cement-coated rods: an effective treatment for infected long bones and prosthetic joint nonunions. Bone Joint J. 2014; 96-B: 1349-54.

14. Conway JD, Hlad LM, Bark SE. Antibiotic cement-coated plates for management of infected fractures. Am J Orthop (Belle Mead NJ). 2015; 44: E49-53.

15. Paley D, Herzenberg JE. Intramedullary infections treated with antibiotic cement rods: preliminary results in nine cases. J Orthop Trauma. 2002; 16: 723-9.

16. Metsemakers WJ, Reul M, Nijs S. The use of gentamicin-coated nails in complex open tibia fracture and revision cases: A retrospective analysis of a single centre case series and review of the literature. Injury. 2015; 46: 2433-7.

17. Antoci V, Phillips MJ, Antoci V, Jr. Krackow KA. Using an antibiotic-impregnated cement rod-spacer in the treatment of infected total knee arthroplasty. Am J Orthop (Belle Mead NJ). 2009; 38: 31-3.

18. Chou DT, Pullinger M, Davis B. A method of fabricating an antibiotic cement spacer using an elastic nail for the treatment of intramedullary osteomyelitis. Ann R Coll Surg Engl. 2015; 97: 157-8.

19. Noh JH, Koh SJ, Lee KH. Treatment of Proximal Femur Osteomyelitis Occurred after Proximal Femoral Nail Antirotation Fixation, with Antibiotic Cement-coated Tibia Intramedullary Nail: A Case Report. Hip Pelvis. 2018; 30: 45-52.

20. Pradhan C, Patil A, Puram C, Attarde D, Sancheti P, Shyam A. Can antibiotic impregnated cement nail achieve both infection control and bony union in infected diaphyseal femoral non-unions? Injury. 2017; 48 Suppl 2: S66-S71.

21. Qiang Z, Jun PZ, Jie XJ, Hang L, Bing LJ, Cai LF. Use of antibiotic cement rod to treat intramedullary infection after nailing: preliminary study in 19 patients. Arch Orthop Trauma Surg. 2007; 127: 945-51

22. Riel RU, Gladden PB. A simple method for fashioning an antibiotic cement-coated interlocking intramedullary nail. Am J Orthop (Belle Mead NJ). 2010; 39: 18-21.

23. Wasko MK, Kaminski R. Custom-Made Antibiotic Cement Nails in Orthopaedic Trauma: Review of Outcomes, New Approaches, and Perspectives. Biomed Res Int. 2015; 2015: 387186.

24. Alt V. Antimicrobial coated implants in trauma and orthopaedics-A clinical review and risk-benefit analysis. Injury. 2017; 48: 599-607.

25. Schmidmaier G, Kerstan M, Schwabe P, Sudkamp N, Raschke M. Clinical experiences in the use of a gentamicin-coated titanium nail in tibia fractures. Injury. 2017; 48: 2235-41.

26. Liporace FA, Yoon RS, Frank MA, Gaines RJ, Maurer JP, Polishchuk DL, et al. Use of an "antibiotic plate" for infected periprosthetic fracture in total hip arthroplasty. J Orthop Trauma. 2012; 26: e18-23.

27. Kühn K. Antibiotic loaded bone cements-antibiotic release and influence on mechanical properties. Local Antibiotics in Arthroplasty: Thieme. 2007.

28. Moghaddam A, Graeser V, Westhauser F, Dapunt U, Kamradt T, Woerner SM, et al. Patients' safety: is there a systemic release of gentamicin by gentamicin-coated tibia nails in clinical use? Ther Clin Risk Manag. 2016; 12: 1387-93.

29. Frommelt L. Antibiotic choices in bone surgery-local therapy using antibiotic loaded bone cement. Local Antibiotics in Arthroplasty: Thieme. 2007; 59. 
30. Karek MR, Jackson NM, Flynn JC, Vaidya R, Markel DC. Elution Profiles of Two Methods of Antibiotic Tibial Nail Preparations. Orthopedics. 2017; 40: e436-e42.

31. Koury KL, Hwang JS, Sirkin M. The Antibiotic Nail in the Treatment of Long Bone Infection: Technique and Results. Orthop Clin North Am. 2017; 48: 155-65.

32. Selhi HS, Mahindra P, Yamin M, Jain D, De Long WG, Jr., Singh J. Outcome in patients with an infected nonunion of the long bones treated with a reinforced antibiotic bone cement rod. J Orthop Trauma. 2012; 26: 184-8.

33. Kanakaris N, Gudipati S, Tosounidis T, Harwood P, Britten S, Giannoudis PV. The treatment of intramedullary osteomyelitis of the femur and tibia using the Reamer-Irrigator-Aspirator system and antibiotic cement rods. Bone Joint J. 2014; 96-B: 783-8

34. Klaue $\mathrm{K}$, Knothe $\mathrm{U}$, Masquelet $\mathrm{A}$. Effet biologique des membranes à corps étranger induites in situ sur la consolidation des greffes d'os spongieux. Rev Chir Orthop Suppl. 1995; 70: 109-10.

35. Sheehy SH, Atkins BA, Bejon P, Byren I, Wyllie D, Athanasou NA, et al. The microbiology of chronic osteomyelitis: prevalence of resistance to common empirical anti-microbial regimens. J Infect. 2010; 60: 338-43.

36. Thakore RV, Greenberg SE, Shi H, Foxx AM, Francois EL, Prablek MA, et al. Surgical site infection in orthopedic trauma: A case-control study evaluating risk factors and cost. J Clin Orthop Trauma. 2015; 6: 220-6.

37. Morgenstern M, Moriarty TF, Kuehl R, Richards RG, McNally MA, Verhofstad MHJ, et al. International survey among orthopaedic trauma surgeons: Lack of a definition of fracture-related infection. Injury. 2018; 49: 491-6.

38. Metsemakers WJ, Kuehl R, Moriarty TF, Richards RG, Verhofstad MHJ, Borens $\mathrm{O}$, et al. Infection after fracture fixation: Current surgical and microbiological concepts. Injury. 2018; 49: 511-22.

39. Rand BC, Penn-Barwell JG, Wenke JC. Combined local and systemic antibiotic delivery improves eradication of wound contamination: An animal experimental model of contaminated fracture. Bone Joint J. 2015; 97-B: 1423-7.

40. Dudareva M, Ferguson J, Riley N, Stubbs D, Atkins B, McNally M. Osteomyelitis of the Pelvic Bones: A Multidisciplinary Approach to Treatment. J Bone Jt Infect. 2017; 2: 184-93.

41. Metsemakers WJ, Onsea J, Neutjens E, Steffens E, Schuermans A, McNally M, et al. Prevention of fracture-related infection: a multidisciplinary care package. Int Orthop. 2017; 41: 2457-69.

42. Toro-Ibarguen A, Moreno-Beamud JA, Porras-Moreno MA, Aroca-Peinado M, Leon-Baltasar JL, Jorge-Mora AA. The number of locking screws predicts the risk of nonunion and reintervention in periprosthetic total knee arthroplasty fractures treated with a nail. Eur J Orthop Surg Traumatol. 2015; 25: 661-4.

43. Thonse R, Conway J. Antibiotic cement-coated interlocking nail for the treatment of infected nonunions and segmental bone defects. J Orthop Trauma. 2007; 21: 258-68

44. Olesen UK, Pedersen NJ, Eckardt H, Lykke-Meyer L, Bonde CT, Singh UM, et al. The cost of infection in severe open tibial fractures treated with a free flap. Int Orthop. 2017; 41: 1049-55.

45. Corona PS, Barro V, Mendez M, Caceres E, Flores X. Industrially prefabricated cement spacers: do vancomycin- and gentamicin-impregnated spacers offer any advantage? Clin Orthop Relat Res. 2014; 472: 923-32.

46. Pino-Minguez J, Jorge-Mora A, Couceiro-Otero R, Garcia-Santiago C. Study of the viability and adhesion of osteoblast cells to bone cements mixed with hydroxyapatite at different concentrations to use in vertebral augmentation techniques. Rev Esp Cir Ortop Traumatol. 2015; 59: 122-8. 